doi:10.4149/neo_2017_115

\title{
FEAT expression correlates with tumor size, PR status, HER2 expression, Ki67 index, and molecular subtype and predicts recurrence in breast cancer
}

\author{
S. M. WANG ${ }^{1,2}$, M. YE ${ }^{2}$, J. ZHOU ${ }^{3}$, S. M. NI ${ }^{2}$, Q. C. WEI ${ }^{1, *}$ \\ ${ }^{1}$ Department of Radiation Oncology, The Second Affiliated Hospital, School of Medicine, Zhejiang University, Hangzhou, Zhejiang 310009 , P. R. \\ China; ${ }^{2}$ Department of Medical Oncology, Affiliated Hospital, School of Medicine, Ningbo University, Ningbo, Zhejiang 315020, P. R. China; \\ ${ }^{3}$ Ningbo Diagnostic Pathology Center, Ningbo, Zhejiang 315021, P. R. China
}

*Correspondence: qichun_wei@zju.edu.cn

Received June 9, 2016/ Accepted September 9, 2016

\begin{abstract}
FEAT protein is uniformly overexpressed in a variety of human cancers but weakly expressed in normal tissue. FEAT has antiapoptotic activity and plays a role in carcinogenesis; however, the correlation between FEAT and clinicopathologic characteristics in cancer has not been reported. Our study explores the expression of FEAT protein and its clinicopathologic significance in breast cancer. We examined the expression of FEAT in tissues from 131 cases of breast cancer by immunohistochemistry and analyzed the correlation between FEAT expression and clinicopathologic parameters. The difference in FEAT expression between normal breast tissues and breast cancer tissues was also investigated. Finally, we analyzed the association between FEAT expression and disease-free survival or overall survival. Our data showed that FEAT was expressed in the cytoplasm. The expression of FEAT protein was significantly higher in breast cancer tissues than in normal breast tissues. Moreover, the expression of FEAT protein was higher in breast cancer with a larger tumor size $(>2 \mathrm{~cm})$, negative PR, positive HER2, or higher Ki67 index $(\geq 14 \%)$ than in breast cancer with a smaller tumor size $(\leq 2 \mathrm{~cm})$, positive PR, negative HER2, or lower Ki67 index $(<14 \%)(P<0.05)$. In addition, the expression of FEAT protein was associated with tumor size, PR status, HER2 expression, Ki67 index, and molecular subtype. Survival analysis showed that disease-free survival and overall survival were significantly shorter in breast cancer patients with high FEAT expression than in those with low expression of FEAT $(P<0.05)$. COX regression analysis showed that FEAT was an independent prognostic factor for recurrence in breast cancer, but not for survival. In conclusion, FEAT may be a potential biomarker for recurrence of breast cancer.
\end{abstract}

Key words: FEAT, breast cancer, clinicopathology, recurrence, prognosis

FEAT protein is encoded by the METTL13 (methyltransferase like 13) gene. The human METTL13 gene is located on chromosome 1q24.3, a region that is often amplified in malignant lymphoma and correlates with prognosis [1-3]. FEAT protein is a member of the methyl transferase superfamily with 699 amino acid residues. Japanese researchers reported that FEAT protein was highly expressed in colon, pancreatic, prostate, breast, ovarian, thyroid, lung, and kidney cancer, but expressed at low levels in normal human tissues [4]. They also found that FEAT had antiapoptotic activity and was involved in carcinogenesis [4]. Because FEAT protein was highly expressed in the majority of human tumors but weakly expressed in normal tissue, Takahashi et al. proposed that it was a characteristic protein of tumors and named it FEAT (faint expression in normal tissues, aberrant overexpression in tumors) [4]. Liang et al. also reported that FEAT protein was highly expressed in lung cancer, breast cancer, and liver cancer tissues, but absent in the corresponding normal tissues [5]. Further study showed that miR-16 promoted apoptosis of tumor cells by silencing FEAT protein through posttranscriptional regulation [5]. These findings indicate that FEAT is an oncoprotein.

However, the correlation of FEAT and clinicopathologic characteristics of cancer and the effect of FEAT on tumor recurrence and prognosis have not been reported. On the basis of former research, we performed immunohistochemistry to examine the expression status of FEAT in breast cancer specimens, and then analyzed its clinicopathologic significance to determine whether it was associated with molecular markers and a predictor of recurrence or survival. 


\section{Patients and methods}

Tissue specimens and patient information. A total of 131 paraffin-embedded tumor specimens from female patients who were histopathologically diagnosed with breast cancer at the Ningbo Diagnostic Pathology Center between February 2006 and January 2009 were used in the present study. None of the patients received chemotherapy, radiotherapy, endocrine therapy, or other anticancer therapy before surgery. Clinical data of the samples are summarized in Table 1 . The median age at the time of surgery was 50 years (range, 30-85 years). Breast cancer tissues from all 131 surgical specimens were used for the detection of FEAT protein. FEAT protein was also detected in paired paracancerous breast tissues and paired normal breast tissues in 40 out of 131 cases. Paracancerous breast tissues or normal breast tissues were defined as breast tissue located less than $5 \mathrm{~cm}$ or more than $5 \mathrm{~cm}$ from the edge

Table 1. Clinicopathologic characteristics of specimens and correlation of FEAT expression and clinicopathologic characteristics in breast cancer patients

\begin{tabular}{|c|c|c|c|c|}
\hline Characteristics & $\begin{array}{l}\text { Total } \\
\text { cases }\end{array}$ & $\begin{array}{c}\text { Cases of high } \\
\text { FEAT } \\
\text { expression(\%) }\end{array}$ & $\begin{array}{c}\text { chi-square } \\
\text { value }\end{array}$ & $P$-value \\
\hline Age (years) & & & 0.316 & 0.574 \\
\hline$<50$ & 64 & $39(60.9 \%)$ & & \\
\hline$\geq 50$ & 67 & $44(65.7 \%)$ & & \\
\hline Tumor grade & & & 0.009 & 0.996 \\
\hline Grade I & 11 & $7(63.6 \%)$ & & \\
\hline Grade II & 73 & $46(63.0 \%)$ & & \\
\hline Grade III & 47 & $30(63.8 \%)$ & & \\
\hline Tumor size & & & 8.608 & 0.003 \\
\hline$>2 \mathrm{~cm}$ & 63 & $48(76.2 \%)$ & & \\
\hline$\leq 2 \mathrm{~cm}$ & 68 & $35(51.5 \%)$ & & \\
\hline Lymph node metastasis & & & 0.434 & 0.510 \\
\hline positive & 65 & $43(66.2 \%)$ & & \\
\hline negative & 66 & $40(60.6 \%)$ & & \\
\hline ER & & & 3.361 & 0.067 \\
\hline positive & 91 & $53(58.2 \%)$ & & \\
\hline negative & 40 & $30(75.0 \%)$ & & \\
\hline PR & & & 6.342 & 0.012 \\
\hline positive & 74 & $40(54.1 \%)$ & & \\
\hline negative & 57 & $43(75.4 \%)$ & & \\
\hline HER2 & & & 9.105 & 0.003 \\
\hline positive & 30 & $26(86.7 \%)$ & & \\
\hline negative & 101 & $57(56.4 \%)$ & & \\
\hline Ki67 index & & & 6.721 & 0.010 \\
\hline$\geq 14 \%$ & 101 & $70(69.3 \%)$ & & \\
\hline$<14 \%$ & 30 & $13(43.3 \%)$ & & \\
\hline Molecular subtype & & & 7.323 & 0.062 \\
\hline Luminal A & 30 & $13(43.3 \%)$ & & \\
\hline Luminal B & 62 & $42(67.7 \%)$ & & \\
\hline HER2 overexpression & 14 & $11(78.6 \%)$ & & \\
\hline Triple negative & 25 & $17(68.0 \%)$ & & \\
\hline
\end{tabular}

of the cancerous tissue respectively. Age, tumor grade, tumor size, and lymph node status, as well as estrogen receptor (ER) status, progesterone receptor (PR) status, human epidermal growth factor receptor 2 (HER2) expression levels, and Ki67 index, were available from the pathologic examination report. HER2 expression was considered to be positive for a score of $3+$ with immunohistochemical staining, whereas scores of 0 or $1+$ were considered to be negative. For cases with HER2 expression score of $2+$ by immunohistochemical staining, only specimens that received HER2 gene detection by fluorescent in situ hybridization(FISH) were included, then HER2 expression was determined by the result of FISH. The follow-up ended in April 2016. Disease-free survival (DFS) was defined as the time from diagnosis to recurrence or last follow-up. Overall survival (OS) was defined as the time from diagnosis to death or last follow-up. Molecular subtypes were classified according to St. Gallen Consensus Conference 2011 as follows: Luminal $\mathrm{A}$ is $\mathrm{ER}$ and/or PR positive, and HER2 negative with a low $\mathrm{Ki} 67$ index (<14\%); Luminal B is ER and/or PR positive and HER2 positive, or ER and/or PR positive and HER2 negative with a high Ki67 index ( $\geq 14 \%)$; HER2 overexpression is ER negative, $\mathrm{PR}$ negative, and HER2 positive; triple negative is ER negative, $\mathrm{PR}$ negative, and HER2 negative. All patients or their guardians provided written consent for the use of these clinical materials for research purposes. This study protocol was approved by the Ethics Committee of the Affiliated Hospital of School of Medicine of Ningbo University.

Immunohistochemistry and assessment. Briefly, paraffinembedded tissues were cut into $4 \mu \mathrm{m}$ sections and baked at $60^{\circ} \mathrm{C}$ for $2 \mathrm{~h}$, followed by deparaffinization with xylenes and rehydration. Antigen retrieval was achieved by heat treatment with Tris-EDTA buffer for 20 min using a microwave, followed by cooling and two washes with PBS. Tissue sections were then treated with $3 \%$ hydrogen peroxide for $5 \mathrm{~min}$ to inactivate endogenous peroxidase, washed with PBS three times, and immersed in blocking buffer for 10 min to block nonspecific binding. After removal of blocking buffer, the tissue sections were covered with Anti-METTL13(FEAT)(Human) mouse monoclonal antibody $(1: 100$, MEDICAL \& BIOLOGICAL LABORATORIES CO.,LTD, Japan), and incubated overnight at $4^{\circ} \mathrm{C}$. For negative controls, the primary antibody was replaced by normal goat serum. After three washes with PBS, the tissue sections were treated with goat polyclonal anti-mouse IgG/HRP polymer (Zhongshan Golden Bridge Biotechnology Co., Ltd., Beijing, China) for $30 \mathrm{~min}$ at room temperature. The sections were washed with PBS three times and covered with DAB substrate solution for 10-20 min, and then washed in distilled water and counterstained with hematoxylin. After a final wash, the tissue sections were dehydrated by immersion in ethanol followed by immersion in xylene, and mounted on slides using permount.

Each slide was scored by two pathologists who were blinded to all clinical data. Cells with cytoplasmic and/or nuclear staining were defined as positive. Ten high-power fields $(400 \times)$ were randomly selected for each section and the percentage 
normal breast
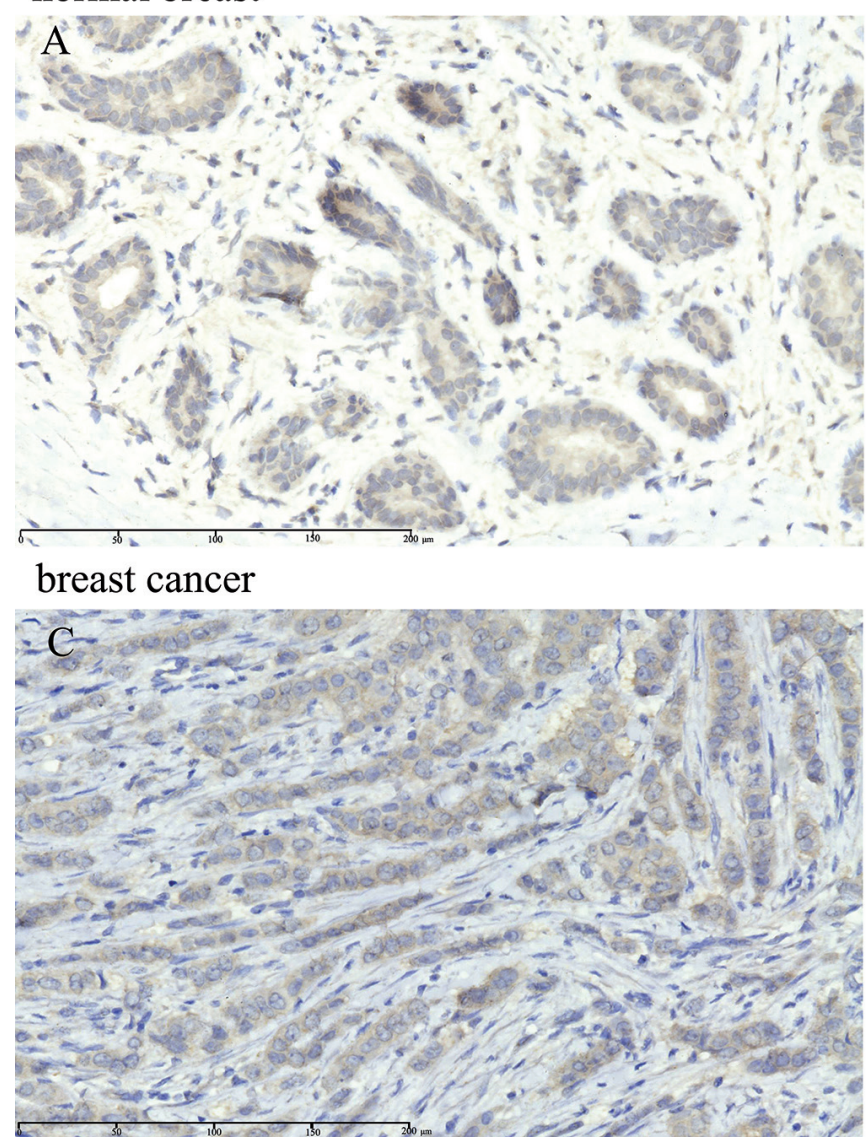

\section{paracancerous breast}

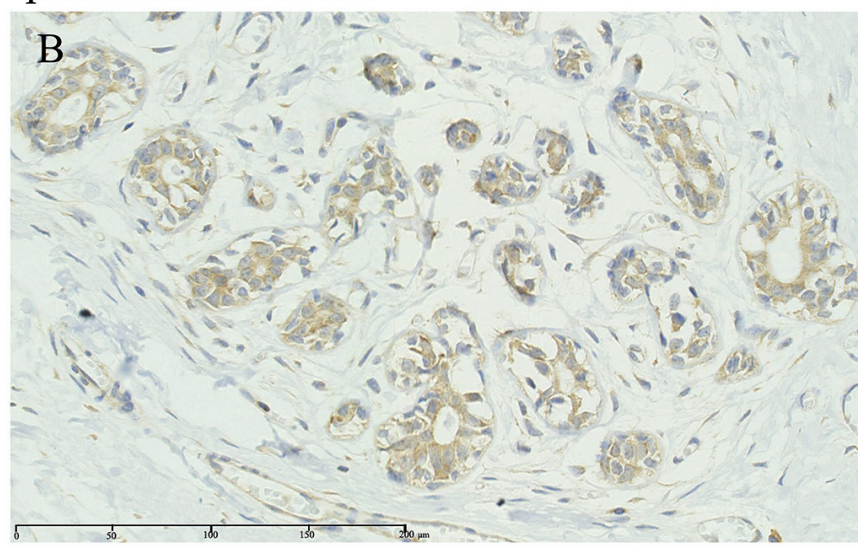

breast cancer

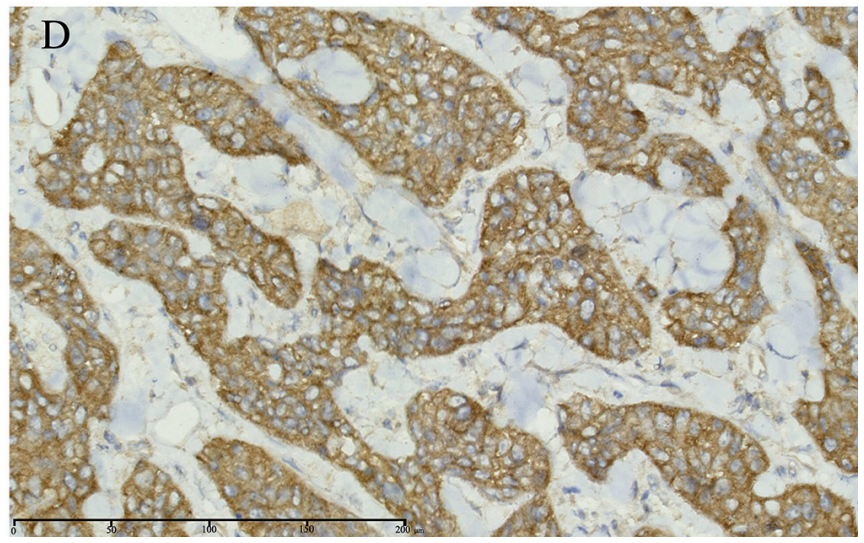

Figure 1. FEAT expression in breast cancer specimens. (A) Low expression of FEAT in normal breast tissues, (B) low expression of FEAT in paracancerous breast tissues, (C) low expression of FEAT in breast cancer tissues, (D) high expression of FEAT in breast cancer tissues. (DAB staining, magnification $\times 400)$

of positive cells in these 10 fields was calculated. The samples were scored according to the percentage of positive cells as follows: $\leq 5 \%=0,6-25 \%=1,26-50 \%=2,51-75 \%=3$, and $>75 \%=4$. Another score was given according to the staining intensity of the majority of cells in each section as follows: no staining $=0$, light yellow $=1$, yellow $=2$, or brown $=3$. The final score for each section was obtained by multiplying these two scores. The cut-off score for FEAT expression was stratified by receiver operating characteristic curve analysis. Final score $\leq 4$ was classified as low expression, and final score $>4$ as high expression.

Statistical analysis. All statistical analyses were carried out using IBM SPSS Statistics 19.0 (IBM Corporation, New York, NY, USA). The chi-square test was used to analyze differences in FEAT expression for different clinicopathologic characteristics. Bivariate correlations between study variables were calculated by Spearman's rank correlation coefficients. Survival analysis was performed by the Kaplan-Meier method, and intergroup differences were calculated by the log-rank test. The significance of various variables for survival was analyzed by univariate and multivariate Cox regression analyses. All reported $P$-values were two-sided. A $P$-value less than 0.05 was considered to be statistically significant.

\section{Results}

FEAT was overexpressed in breast cancer tissues. Immunohistochemical staining of breast cancer specimens showed that FEAT protein was detectable in the cytoplasm of tumor cells and normal breast cells, but not in the nuclei (Figure 1). The expression of FEAT protein was significantly higher in breast cancer tissues than in paracancerous breast tissues and normal breast tissues of 40 breast specimens examined $\left(\chi^{2}=14.729, P=0.001\right)$ (Figure 1, Table 2).

FEAT expression level was associated with clinicopathologic features. Statistical analysis by chi-square test was performed to evaluate the correlation of FEAT expression with clinicopathologic parameters of breast cancer. As summarized in Table 1, the expression of FEAT protein was higher in breast cancer tissues with a larger tumor size 

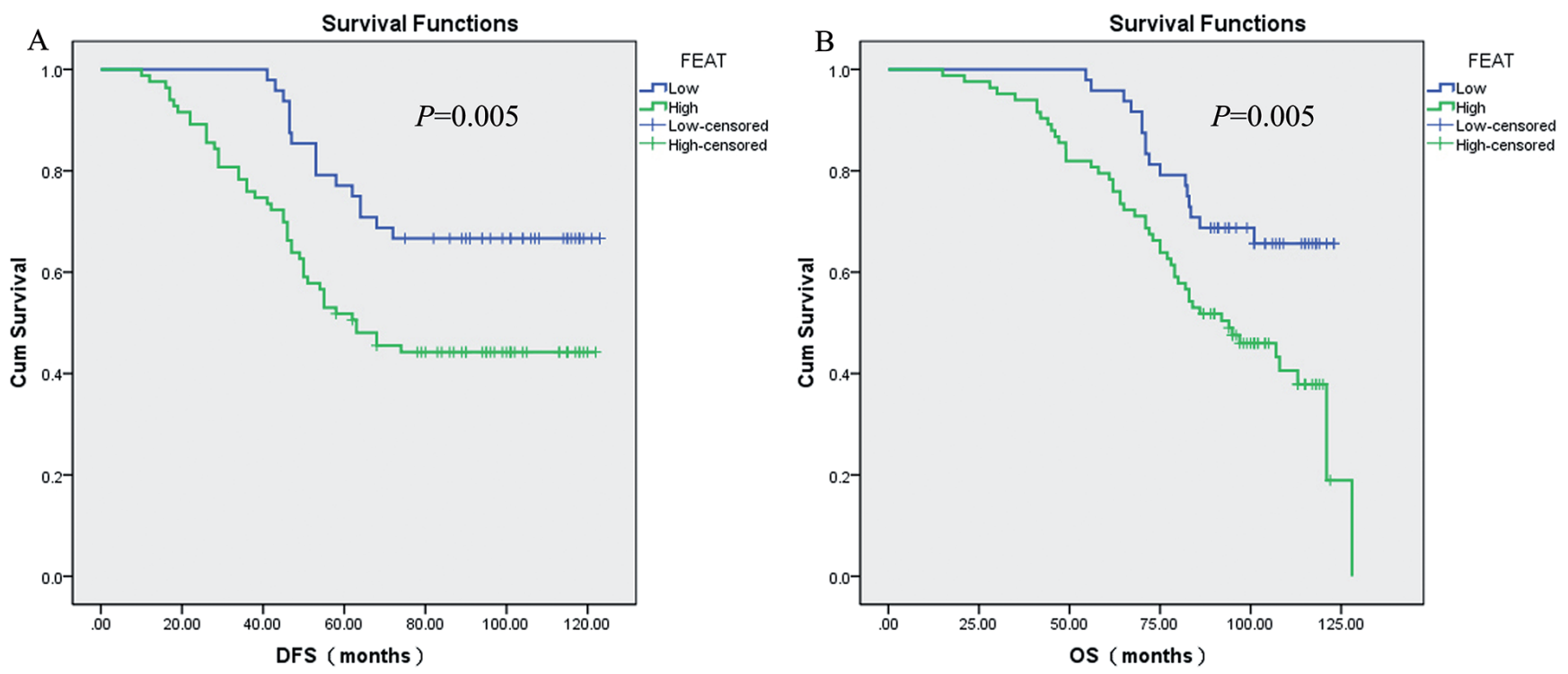

Figure 2. Kaplan-Meier graph of breast cancer patients with low and high FEAT expression. (A) Disease-free survival (DFS) (chi-square value=7.897, $P=0.005$ ), (B) overall survival (OS) (chi-square value $=7.991, P=0.005)$.

$(>2 \mathrm{~cm})(P=0.003)$, negative $\mathrm{PR}(P=0.012)$, positive HER2 $(P=0.003)$, or a higher Ki67 index $(\geq 14 \%)(P=0.010)$ than in breast cancer tissues with a smaller size $(\leq 2 \mathrm{~cm})$, positive $P R$, negative HER2, or a lower Ki67 index (<14\%). However, there was no significant difference in FEAT expression in breast cancer tissues according to patient age $(\geq 50$ or $<50)$, tumor grade (Grade I, Grade II, or Grade III), lymph node metastases (positive or negative), expression of ER (negative or positive), or molecular subtype $(P>0.05)$. Spearman correlation analysis suggested that the FEAT expression level was strongly associated with tumor size $(\mathrm{r}=0.256, P=0.003), \mathrm{PR}$ status $(\mathrm{r}=-0.220$, $P=0.012)$, HER2 expression levels $(r=0.264, P=0.002)$, Ki67 index ( $\mathrm{r}=0.227, P=0.009)$, and molecular subtype $(\mathrm{r}=0.190$, $P=0.030$ ) (Table 3 ).

FEAT expression level predicts recurrence of breast cancer. Kaplan-Meier analysis showed that the DFS rate of breast cancer with high FEAT expression was significantly lower than that of breast cancer with low FEAT expression (log-rank test, chi-square value $=7.897, P=0.005)$ (Figure 2 ).

Table 2. Different expression of FEAT in breast cancer, paracancerous breast tissues and normal breast tissues

\begin{tabular}{lccc}
\hline Specimens & $\begin{array}{c}\text { Cases of high } \\
\text { FEAT } \\
\text { expression(\%) }\end{array}$ & $\begin{array}{c}\text { chi-square } \\
\text { value }\end{array}$ & P-value \\
\hline breast cancer tissues & $27 / 40(67.5 \%)$ & 14.729 & 0.001 \\
paracancerous breast tissues & $14 / 40(35.0 \%)$ & & \\
normal breast tissues & $11 / 40(27.5 \%)$ & & \\
& & & \\
\hline
\end{tabular}

note: comparison of paracancerous breast tissues and normal breast tissues: chi-square value $=0.524 P=0.469$
Similarly, the OS rate of breast cancer with high FEAT expression was significantly lower than that of breast cancer with low FEAT expression (log-rank test, chi-square value $=7.991$, $P=0.005$ ) (Figure 2). Univariate Cox regression analysis showed that tumor size, lymph node metastasis, ER status, and FEAT expression levels were risk factors for recurrence in breast cancer $(P<0.05)$, and further multivariate Cox regression analysis showed that all four variables were independent prognostic factors for recurrence $(P<0.05)$ (Table 4$)$. Univariate Cox regression analysis showed that tumor size, lymph node metastasis, ER status, PR status, Ki67 index, FEAT expression level, and molecular subtype were prognostic risk factors in breast cancer $(P<0.05)$, but further multivariate Cox regression analysis showed that only tumor size, lymph node metastasis, Ki67 index, and molecular subtype were independent prognostic factors for survival $(P<0.05)$ (Table 5$)$.

Table 3. Spearman correlation analysis of FEAT and clinicopathologic factors

\begin{tabular}{lcc}
\hline Variables & \multicolumn{2}{c}{ FEAT expression } \\
\cline { 2 - 3 } & Spearman correlation(r) & $\boldsymbol{P}$-Value \\
\hline Age & 0.049 & 0.577 \\
Tumor grade & 0.006 & 0.949 \\
Tumor size & 0.256 & 0.003 \\
Lymph node metastasis & 0.058 & 0.514 \\
Expression of ER & -0.160 & 0.068 \\
Expression of PR & -0.220 & 0.012 \\
Expression of HER2 & 0.264 & 0.002 \\
Ki67 index & 0.227 & 0.009 \\
Molecular subtype & 0.190 & 0.030 \\
\hline
\end{tabular}


Table 4. Univariate and multivariate Cox regression analyses of potential factors for DFS in breast cancer patients

\begin{tabular}{|c|c|c|c|c|c|c|}
\hline & \multicolumn{3}{|c|}{ Univariate analysis } & \multicolumn{3}{|c|}{ Multivariate analysis } \\
\hline & $P$ & $\operatorname{Exp}(B)$ & $95 \% \mathrm{CI}$ & $P$ & $\operatorname{Exp}(B)$ & $95 \% \mathrm{CI}$ \\
\hline \multicolumn{7}{|l|}{ Age (years) } \\
\hline$<50$ & 0.233 & 0.736 & $0.444-1.218$ & & & \\
\hline$\geq 50$ & & 1 & & & & \\
\hline Tumor grade & 0.304 & & & & & \\
\hline Grade I & 0.675 & 0.815 & $0.314-2.119$ & & & \\
\hline Grade II & 0.123 & 0.664 & $0.395-1.117$ & & & \\
\hline Grade III & & 1 & & & & \\
\hline \multicolumn{7}{|l|}{ Tumor size } \\
\hline$\leq 2 \mathrm{~cm}$ & 0.003 & 0.463 & $0.279-0.770$ & 0.038 & 0.576 & $0.342-0.969$ \\
\hline$>2 \mathrm{~cm}$ & & 1 & & & 1 & \\
\hline \multicolumn{7}{|l|}{ Lymph node metastasis } \\
\hline negative & 0.000 & 0.285 & $0.164-0.496$ & 0.000 & 0.264 & $0.150-0.462$ \\
\hline positive & & 1 & & & 1 & \\
\hline \multicolumn{7}{|l|}{ ER } \\
\hline negative & 0.009 & 1.959 & $1.182-3.247$ & 0.012 & 1.928 & $1.157-3.214$ \\
\hline positive & & 1 & & & 1 & \\
\hline \multicolumn{7}{|l|}{ PR } \\
\hline negative & 0.284 & 1.313 & $0.798-2.162$ & & & \\
\hline positive & & 1 & & & & \\
\hline \multicolumn{7}{|l|}{ HER2 } \\
\hline negative & 0.227 & 0.704 & $0.398-1.244$ & & & \\
\hline positive & & 1 & & & & \\
\hline \multicolumn{7}{|l|}{ Ki67 index } \\
\hline$<14 \%$ & 0.109 & 0.575 & $0.292-1.131$ & & & \\
\hline$\geq 14 \%$ & & 1 & & & & \\
\hline \multicolumn{7}{|l|}{ FEAT expression } \\
\hline low & 0.007 & 0.453 & $0.256-0.802$ & 0.015 & 0.483 & $0.269-0.868$ \\
\hline high & & 1 & & & 1 & \\
\hline Molecular subtype & 0.075 & & & & & \\
\hline Luminal A & & 1 & & & & \\
\hline Luminal B & 0.323 & 1.439 & $0.699-2.965$ & & & \\
\hline HER2 overexpression & 0.016 & 3.022 & $1.225-7.455$ & & & \\
\hline Tripe negative & 0.085 & 2.020 & $0.907-4.500$ & & & \\
\hline
\end{tabular}

\section{Discussion}

FEAT is a member of the methyl transferase superfamily proteins and contains two S-adenosylmethionine-binding motifs (SAM-binding motifs) that are characteristic of methyltransferases and related enzymes. FEAT can bind SAM [6], and therefore theoretically should have methyl transferase activity. Methylation plays an important role in the development, diagnosis, and treatment of breast cancer [7-9]. However, in the study by Takahashi et al., FEAT methyltransferase activity, spermidine/spermine synthase activity, or ubiquinone synthase activity were not detected, and further studies are required to determine whether FEAT has enzymatic activities [4]. Gene expression profiling suggested that FEAT could drive receptor tyrosine kinase and Hedgehog signaling pathways and inhibit cell apoptosis [4]. In diffuse large B-cell lymphoma, hypermethylation and low expression of the METTL13 gene encoding FEAT was detected in cell lines resistant to temozolomide, but not in cell lines sensitive to temozolomide [10]. These studies indicate that FEAT protein is an antiapoptotic protein and further suggest that FEAT might affect the formation and development of tumors and drug sensitivity through a molecular biological mechanism. Other studies showed that the METTL13 gene was associated with mental and psychological illness. A single nucleotide polymorphism in the human METTL13 gene was related to increased susceptibility to postpartum mood syndrome [11]. CpG-island microarray analyses of frontal cortex tissues revealed increased DNA methylation close 
Table 5. Univariate and multivariate Cox regression analyses of potential factors for OS in breast cancer patients

\begin{tabular}{|c|c|c|c|c|c|c|}
\hline & \multicolumn{3}{|c|}{ Univariate analysis } & \multicolumn{3}{|c|}{ Multivariate analysis } \\
\hline & $P$ & $\operatorname{Exp}(B)$ & $95 \% \mathrm{CI}$ & $P$ & $\operatorname{Exp}(B)$ & $95 \% \mathrm{CI}$ \\
\hline \multicolumn{7}{|l|}{ Age (years) } \\
\hline$<50$ & 0.613 & 1.134 & $0.697-1.845$ & & & \\
\hline$\geq 50$ & & 1 & & & & \\
\hline Tumor grade & 0.089 & & & & & \\
\hline Grade I & 0.270 & 0.555 & $0.195-1.580$ & & & \\
\hline Grade II & 0.034 & 0.580 & $0.350-0.960$ & & & \\
\hline Grade III & & 1 & & & & \\
\hline \multicolumn{7}{|l|}{ Tumor size } \\
\hline$\leq 2 \mathrm{~cm}$ & 0.000 & 0.393 & $0.236-0.655$ & 0.027 & 0.545 & $0.317-0.934$ \\
\hline$>2 \mathrm{~cm}$ & & 1 & & & 1 & \\
\hline \multicolumn{7}{|l|}{ Lymph node metastasis } \\
\hline negative & 0.000 & 0.333 & $0.196-0.566$ & 0.000 & 0.326 & $0.187-0.567$ \\
\hline positive & & 1 & & & 1 & \\
\hline \multicolumn{7}{|l|}{ ER } \\
\hline negative & 0.007 & 1.975 & $1.201-3.247$ & 0.996 & 0.996 & $0.286-3.476$ \\
\hline positive & & 1 & & & 1 & \\
\hline \multicolumn{7}{|l|}{ PR } \\
\hline negative & 0.010 & 1.901 & $1.166-3.099$ & 0.666 & 1.175 & $0.565-2.444$ \\
\hline positive & & 1 & & & 1 & \\
\hline \multicolumn{7}{|l|}{ HER2 } \\
\hline negative & 0.069 & 0.602 & $0.348-1.040$ & & & \\
\hline positive & & 1 & & & & \\
\hline \multicolumn{7}{|l|}{ Ki67 index } \\
\hline$<14 \%$ & 0.023 & 0.442 & $0.218-0.893$ & 0.023 & 0.383 & $0.167-0.878$ \\
\hline$\geq 14 \%$ & & 1 & & & 1 & \\
\hline \multicolumn{7}{|l|}{ FEAT expression } \\
\hline low & 0.006 & 0.454 & $0.258-0.799$ & 0.098 & 0.602 & $0.330-1.098$ \\
\hline high & & 1 & & & 1 & \\
\hline Molecular subtype & 0.024 & & & 0.022 & & \\
\hline Luminal A & & 1 & & & 1 & \\
\hline Luminal B & 0.098 & 1.872 & $0.891-3.935$ & 0.419 & 1.367 & $0.640-2.919$ \\
\hline HER2 overexpression & 0.006 & 3.625 & $1.435-9.155$ & 0.018 & 3.110 & $1.217-7.945$ \\
\hline Tripe negative & 0.013 & 2.822 & $1.245-6.395$ & 0.023 & 2.609 & $1.139-5.978$ \\
\hline
\end{tabular}

to the METTL13 gene among female patients with bipolar disorder and psychosis [12].

Breast cancer is the second most common human tumor overall and the most frequent cancer in female individuals [13]. Breast cancer involves multiple signaling pathways and displays distinct molecular characteristics [14]. Therapeutic options for breast cancer and patient survival have improved significantly with increased understanding of the molecular characteristics of the disease and the emergence of personalized treatment. ER, PR, and HER2 affect the formation and development of breast cancer, and are also prognostic factors [15]. The Ki67 index, as a nuclear proliferation marker, is associated with proliferation ability and prognosis, and also predicts therapy outcomes in breast cancer [16-19]. Subtyping on the basis of molecular expression plays an important role in the treatment and prognosis of breast cancer [20].
Further exploration of the molecular characteristics of breast cancer will lead to better understanding of breast cancer and guide personalized treatment. On the basis of previous research, this study analyzed the correlation of FEAT protein with clinicopathologic characteristics of breast cancer. Our results demonstrated that the expression of FEAT protein was significantly higher in breast cancer tissues than in normal breast tissues. In addition, higher FEAT protein expression was associated with larger tumors and a higher Ki67 index. The expression of FEAT protein was associated with PR status, HER2 expression, and molecular subtype. Expression of FEAT was upregulated in breast cancer tissues with negative PR and positive HER2 status. Furthermore, FEAT expression was higher in ER-negative breast cancer than in ER-positive breast cancer, but without significance. Although a correlation clearly exists between FEAT and these receptors, further mo- 
lecular biology experiments are required to confirm whether they regulate each other. Receptor status has great value for guiding the treatment of breast cancer as breast cancer patients with positive hormone receptor status can benefit from endocrine therapy. Anti-HER2 treatment is a good choice for breast cancer with positive HER2. In contrast, patients with triple-negative breast cancer cannot receive endocrine therapy or anti-HER2 treatment, and HER2 overexpressing breast cancer is not usually suitable for endocrine therapy. As a result, prognosis is typically poor in patients with triple-negative or HER2 overexpressing breast cancer. Our data showed that FEAT protein expression was high in more than two-thirds of these patients (Table 1), suggesting that the development of therapy targeting FEAT might benefit the treatment of these patients.

Larger tumor size, PR-negative, ER-negative, HER2-positive, and a higher Ki67 index predict recurrence and poor prognosis for patients with breast cancer $[15,19]$. As FEAT expression correlates with these standard indicators, FEAT should be another prognostic factor for breast cancer. To investigate this, we performed further survival analysis. Consistent with other studies [18, 21-23], we showed that tumor size, lymph node metastasis, Ki67 index, and molecular subtype were independent prognostic factors for breast cancer. In our study, high FEAT expression indicated low DFS and OS rates. In addition, high FEAT expression was an independent prognostic factor for recurrence, thus breast cancer patients with high FEAT expression have a high risk of recurrence. Some breast cancer patients that are considered as low recurrence risk according to current definitions may actually be at a high risk of recurrence if they have high FEAT expression. Although high FEAT expression is an independent risk factor for recurrence in breast cancer, it is not an independent prognosis factor. Thus, although high FEAT expression is helpful to predict the recurrence and metastasis of breast cancer, it does not affect the survival of patients. Similarly, the clinicopathologic significance of other parameters is different between DFS and OS in our study. Tumor size, lymph node metastasis, ER status and FEAT expression levels are independent prognostic factors for recurrence, while tumor size, lymph node metastasis, Ki67 index, and molecular subtype are independent prognostic factors for survival. The difference might be caused by drug sensitivity because OS is more susceptible to anticancer therapy than DFS. Tumor size and lymph node metastasis usually have no impact on drug sensitivity, so both of these parameters are independent prognostic factors for recurrence and survival. ER, FEAT, Ki67 and molecular subtype as molecular markers can change drug sensitivity $[10,16,19,24]$, and might result in the difference. Although under-expressed METTL13 gene relates to temozolomide resistance in lymphoma cell lines[10], the impact of FEAT on drug resistance in breast cancer remains to be verified.

In conclusion, this study demonstrates that FEAT expression in the cytoplasm is higher in breast cancer tissues than in normal breast tissues, implicating FEAT as a potential bi- omarker of breast cancer. In addition, high FEAT expression is associated with a large tumor, negative PR, positive HER2, high Ki67 index, and molecular subtype. This study also shows that high FEAT expression is a biomarker of early recurrence in breast cancer. However, further studies are necessary to confirm whether FEAT can be used as a biomarker for the diagnosis and treatment of tumors. Similarly, its molecular biological function, related signal regulation pathways, and enzyme activity should be elucidated.

Acknowledgments: We wish to thank Kwok Cheung LEE, a professor at Georgetown University, for language editing. This work was supported by grants from the Natural Science Foundation of Ningbo City (No. 2016A610124) and the Scientific Research Project of Ningbo University (No. XYY14003).

\section{References}

[1] DIERLAMM J, ROSENBERG C, STUL M, PITTALUGA S, WLODARSKA I et al. Characteristic pattern of chromosomal gains and losses in marginal zone B cell lymphoma detected by comparative genomic hybridization. Leukemia 1997; 11: 747-758. https:/doi.org/10.1038/sj.leu.2400635

[2] BARTH TF, DOHNER H, WERNER CA, STILGENBAUER S, SCHLOTTER $M$ et al. Characteristic pattern of chromosomal gains and losses in primary large B-cell lymphomas of the gastrointestinal tract. Blood 1998; 91: 4321-4330.

[3] RICKERT CH, DOCKHORN-DWORNICZAK B, SIMON R, PAULUS W. Chromosomal imbalances in primary lymphomas of the central nervous system. Am J Pathol 1999; 155: 1445-1451. https:/doi.org/10.1016/S0002-9440(10)65458-2

[4] TAKAHASHI A, TOKITA H, TAKAHASHI K, TAKEOKA T, MURAYAMA K et al. A novel potent tumour promoter aberrantly overexpressed in most human cancers. Sci Rep 2011; 1: 15. https:/doi.org/10.1038/srep00015

[5] LIANG H, FU Z, JIANG X, WANG N, WANG F et al. miR-16 promotes the apoptosis of human cancer cells by targeting FEAT. BMC Cancer 2015; 15: 448. https:/doi.org/10.1186/ $\underline{\text { s12885-015-1458-8 }}$

[6] WIRSING L, NAUMANN K, VOGT T. Arabidopsis methyltransferase fingerprints by affinity-based protein profiling. Anal Biochem 2011; 408: 220-225. https:/doi.org/10.1016/j. ab.2010.09.029

[7] SUBRAMANIAM D, THOMBRE R, DHAR A, ANANT S. DNA methyltransferases: a novel target for prevention and therapy. Front Oncol 2014; 4: 80. https:/doi.org/10.3389/ fonc.2014.00080

[8] WITTENBERGER T, SLEIGH S, REISEL D, ZIKAN M, WAHL B et al. DNA methylation markers for early detection of women's cancer: promise and challenges. Epigenomics 2014; 6: 311-327. https:/doi.org/10.2217/epi.14.20

[9] WARTON K, SAMIMI G. Methylation of cell-free circulating DNA in the diagnosis of cancer. Front Mol Biosci 2015; 2: 13. https:/doi.org/10.3389/fmolb.2015.00013

[10] LESHCHENKO VV, KUO PY, JIANG Z, THIRUKONDA VK, PAREKH S. Integrative genomic analysis of temozolomide 
resistance in diffuse large B-cell lymphoma. Clin Cancer Res 2014; 20: 382-392. https:/doi.org/10.1158/1078-0432.CCR13-0669

[11] MAHON PB, PAYNE JL, MACKINNON DF, MONDIMORE FM, GOES FS et al. NIMH Genetics Initiative Bipolar Disorder Consortium; BiGS Consortium, Coryell WH, et al: Genome-wide linkage and follow-up association study of postpartum mood symptoms. Am J Psychiatry 2009; 166: 1229-1237. https:/doi.org/10.1176/appi. ajp.2009.09030417

[12] MILL J, TANG T, KAMINSKY Z, KHARE T, YAZDANPANAH $S$ et al. Epigenomic profiling reveals DNA-methylation changes associated with major psychosis. Am J Hum Genet 2008; 82: 696-711. https:/doi.org/10.1016/j.ajhg.2008.01.008

[13] FERLAY J, SOERJOMATARAM I, DIKSHIT R, ESER $S$, MATHERS $C$ et al. Cancer incidence and mortality worldwide: sources, methods and major patterns in GLOBOCAN2012. Int J Cancer 2015; 136: E359-386. https:/doi. org/10.1002/ijc.29210

[14] KOBOLDT DC, FULTON RS, MCLELLAN MD, SCHMIDT H, KALICKI-VEIZER J et al. Comprehensive molecular portraits of human breast tumours. Nature 2012 490: 61-70. https:/doi.org/10.1038/nature11412

[15] ESTEVA FJ SAHIN AA, CRISTOFANILLI M, ARUN B, HORTOBAGYI GN. Molecular prognostic factors for breast cancer metastasis and survival. Semin Radiat Oncol 2002; 12: 319-328. https:/doi.org/10.1053/srao.2002.35251

[16] ROCCA A, FAROLFI A, MALTONI R, CARRETTA E, MELEGARI $E$ et al. Efficacy of endocrine therapy in relation to progesterone receptor and Ki67 expression in advanced breast cancer. Breast Cancer Res Treat 2015; 152: 57-65. https:/doi. org/10.1007/s10549-015-3423-2

[17] SHUI R, YU B, BI R, YANG F, YANG W. An interobserver reproducibility analysis of ki67 visual assessment in breast cancer. PLoS One 2015; 10: e0125131. https:/doi.org/10.1371/ journal.pone.0125131
[18] INWALD EC, KLINKHAMMER-SCHALKE M, HOFSTADTER F, ZEMAN F, KOLLER M et al. Ki-67 is a prognostic parameter in breast cancer patients: results of a large population-based cohort of a cancer registry. Breast Cancer Res Treat 2013; 139: 539-552. https:/doi.org/10.1007/s10549-013 $-2560-8$

[19] YERUSHALMI R, WOODS R, RAVDIN PM, HAYES MM, GELMON KA. Ki67 in breast cancer: prognostic and predictive potential. Lancet Oncol 2010; 11: 174-83. https:/doi. org/10.1016/S1470-2045(09)70262-1

[20] CADOO KA, FORNIER MN, MORRIS PG. Biological subtypes of breast cancer: current concepts and implications for recurrence patterns. Q J Nucl Med Mol Imaging 2013; 57: 312-321.

[21] SAADATMAND S, BRETVELD R, SIESLING S, TILANUSLINTHORST MM. Influence of tumour stage at breast cancer detection on survival in modern times: population based study in 173,797 patients. BMJ 2015 351: h4901. https:/doi. org/10.1136/bmj.h4901

[22] TOBIN NP, HARRELL JC, LOVROT J, EGYHAZI BRAGE S, FROSTVIK STOLT M et al. Molecular subtype and tumor characteristics of breast cancer metastases as assessed by gene expression significantly influence patient post-relapse survival. Ann Oncol 2015; 26: 81-88. https:/doi.org/10.1093/ annonc/mdu498

[23] PUIG-VIVES M, SANCHEZ MJ, SANCHEZ-CANTALEJO J, TORRELLA-RAMOS A, MARTOS C et al. Distribution and prognosis of molecular breast cancer subtypes defined by immunohistochemical biomarkers in a Spanish populationbased study. Gynecol Oncol 2013; 130: 609-614. https:/doi. org/10.1016/j.ygyno.2013.05.039

[24] MARTIN M, ROMERO A, CHEANG MC, LOPEZ GARCIAASENJO JA, GARCIA-SAENZ JA et al. Genomic predictors of response to doxorubicin versus docetaxel in primary breast cancer. Breast Cancer Res Treat 2011; 128: 127-136. https:/ doi.org/10.1007/s10549-011-1461-y 